\title{
Erratum to: BayesFlow: latent modeling of flow cytometry cell populations
}

Kerstin Johnsson ${ }^{*^{*}+}$, Jonas Wallin ${ }^{2 \dagger}$ and Magnus Fontes ${ }^{1,3}$

Unfortunately, the original version of this article [1] contained an error whereby the figures are completely out of order. The correct order of figures is as below. For example, Figure 1 should be the first figure, Figure 6 should be the second figure, Figure 2 should be the third figure and so forth as listed below. This has been corrected in the original article.

Fig. 1

Fig. 6

Fig. 2

Fig. 3

Fig. 7

Fig. 8

Fig. 9

Fig. 10

Fig. 11

Fig. 12

Fig. 13

Fig. 4

Fig. 5

Fig. 14

\section{Author details}

${ }^{1}$ Centre for Mathematical Sciences, Lund University, Box 118, S-221 00 Lund, Sweden. ${ }^{2}$ Mathematical Sciences, Chalmers and University of Gothenburg, S-412 58 Gothenburg, Sweden. ${ }^{3}$ International Group for Data Analysis, Institut Pasteur, 25 Rue du Docteur Roux, 75015 Paris, France.

Received: 1 March 2016 Accepted: 1 March 2016

Published online: 31 March 2016

\section{Reference}

1. Johnsson K, Wallin J, Fontes M. BayesFlow: latent modeling of flow cytometry cell populations. BMC Bioinformatics. 2016;17:25.

* Correspondence: johnsson@maths.lth.se

${ }^{\dagger}$ Equal contributors

${ }^{1}$ Centre for Mathematical Sciences, Lund University, Box 118, S-221 00 Lund, Sweden

Full list of author information is available at the end of the article

Submit your next manuscript to BioMed Central and we will help you at every step:

- We accept pre-submission inquiries

- Our selector tool helps you to find the most relevant journal

- We provide round the clock customer support

- Convenient online submission

- Thorough peer review

- Inclusion in PubMed and all major indexing services

- Maximum visibility for your research

Submit your manuscript at www.biomedcentral.com/submit
() Biomed Central 